\title{
Chapter 12 \\ Diaspora Policies, Consular Services and Social Protection for German Citizens Abroad
}

\author{
Amanda Klekowski von Koppenfels
}

\subsection{Introduction}

This chapter presents the interactions of the German Government with its nationals abroad, focusing on the policies adopted for this specific population, and presenting the institutions and legal bases that are in place, with a focus on social protection. Overall, the picture which emerges, and which is presented in this chapter, is that of a country which has neither an explicit emphasis on its emigrants nor many policies intended specifically for them. For the most part, rights in Germany are residencebased, and access to rights is thus associated with (legal) residence in the country, rather than with holding German citizenship. There are two clear exceptions: one is a robust system which enables voting from abroad for German citizens, and the other is facilitated access from abroad to pensions for years worked in Germany.

Policies vis-à-vis nationals residing abroad, as limited as they are, are otherwise folded into the relevant ministries, with discretion exercised by consular officials playing an important role in accessing those benefits. There are provisions to allow German nationals living abroad to be included in various policies (such as access to unemployment insurance or health insurance) under certain conditions, but these are rarely stated explicitly and function more often on the basis of exception rather than rule or law.

This lack of targeted policies for non-resident nationals contrasts with specific policies and structures for German minorities in Central and Eastern Europe (CEE), the former Soviet Union and southern Denmark. In what has been called an "historical legacy" (Cordell and Wolff 2007), including post-war reconciliation, clear policies have been developed for these populations. These policies largely facilitate German minorities' continued or emerging engagement with German language and

\footnotetext{
A. Klekowski von Koppenfels ( $\square)$

Brussels School of International Studies, University of Kent, Brussels, Belgium

e-mail: ak248@kent.ac.uk
} 
culture. They are restricted to German minorities which have been created by border movements (such as those in southern Denmark), or directly affected by Nazi occupation and World War II (such as those in Central and Eastern Europe and the countries of the former Soviet Union). That is to say, these are not policies which extend to ethno-national German minorities elsewhere in the world.

The German policy vis-à-vis Germans - defined broadly - outside of Germany in the post-World War II era is thus characterized by a contrast between a benign neglect of German nationals abroad and a concerted cultural outreach to ethnonational German minorities in Central and Eastern Europe. This contrast can largely be explained by historical legacies of Germany as an emigration country, which extended well into the 1950s, coupled with a post-war Vergangenheitsbewältigung (coming to terms with the past), or post-war reconciliation, perspective.

\subsection{Diaspora Characteristics and Home Country Engagement}

\subsubsection{The German Diaspora and Its Relations with the Homeland}

Germany was long known as an "undeclared" (Thränhardt 1995) or "reluctant" (Martin 1994) country of immigration, with so-called guestworker (Gastarbeiter) migration from the 1950 s and 1960s initially envisaged as temporary, and only belatedly understood - in 2000 - as a permanent immigration flow (e.g. Brodmerkel 2017; Schmidtke 2017). In addition to substantial migration of ethnic Germans from Central and Eastern Europe and the former Soviet Union (Aussiedler), with a peak of 400,000 in 1990 (Klekowski von Koppenfels 2009), this temporary-turnedpermanent migration flow has contributed to the solid recognition of Germany as an immigration country (Klekowski von Koppenfels and Höhne 2017).

There was high emigration from Germany, both before its unification in 1871, and after. Prior to German unification, Empress Catherine II of Russia, herself born in Prussia, called on German settlers in 1763 to work un-farmed land in Russia. Some 30,000 Germans responded within the next 30 years, forming the basis for the ethno-national German minority living in Russia (Klekowski von Koppenfels 2002). Germany's shifting borders over the centuries also resulted in German migration across what are now CEE countries. Their descendants constitute the ethno-national German minorities still living in these countries.

Germany's late unification as a modern nation-state in 1871, which brought together 26 states in a federation, coincided with high migration not only among those states, but also with high emigration to the United States (US), with more than 1 million emigrants to the US during the 1880s alone, and 5.5 million between 1816 and 1914 (Bade 1995: 511). High emigration continued into the post-war era, with 
net migration consistently negative until 1956, when guestworker recruitment exceeded emigration. Net migration was negative most recently in 2008 and 2009. ${ }^{1}$

From 1967 to 2013, there has been an overall net emigration of some 1.4 million German citizens ${ }^{2}$; it is not known, however, how many of those have since returned to Germany. Germany continues to have a substantial number of emigrants, whether temporary or permanent, with 250,000 leaving in 2017 alone, ${ }^{3}$ but, like many other countries in the Global North, Germany has not established strong institutional links with those emigrants. Data on those leaving the country is based on those who have de-registered from a German residence. The German Government does not have any formal estimate of the number of German citizens living abroad (Drs. 18/13579). They note that there are two factors which prevent one single accurate figure from being achieved, first, that German citizenship can be acquired abroad through birth to a German citizen, and, second, that temporary emigrants cannot be distinguished in emigration (=de-registration) data from permanent emigrants.

The Organisation for Economic Cooperation and Development (OECD) estimated 3.7 million German citizens living in other OECD countries as of 2010/11; this was the third-largest national group of emigrants in the OECD region, behind Mexico and the UK. Within the OECD group, the largest numbers of German citizens were in the United States (1.1 million), followed by the United Kingdom $(275,000)$, Switzerland (274,000), France $(207,000)$, Italy $(192,000)$, Spain $(186,000)$, Canada (165,000), Austria $(153,000)$, Turkey $(136,000)$ and the Russian Federation $(135,000)$ (OECD 2015, 127). ${ }^{4}$ In 2013, the UN estimated just under 2 million German citizens living abroad, with the US, Turkey, Switzerland, the UK and Spain as the top five destinations. ${ }^{5}$ These discrepancies are not unique; reliable data on emigration are notoriously difficult to find (Klekowski von Koppenfels and Costanzo 2013).

Contemporary emigrants are, according to an SVR study ${ }^{6}$ which sampled among Germans who had de-registered and left Germany during 2013, considerably younger than non-emigrants (on average, emigrants are 37 years old compared to the average of 50 for the non-migrants). They are also more highly educated, with

\footnotetext{
${ }^{1}$ https://www.destatis.de/EN/FactsFigures/SocietyState/Population/Migration/Tables_/lrbev07. html;jsessionid=D91ACD3B76E67029C59A109D20918B39.InternetLive1. Last accessed 30 April 2020.

${ }^{2}$ SVR (2015). Internationally mobile: motivations, determining factors and impacts of the emigration and return migration of German Citizens. https://www.svr-migration.de/en/publications/ internationally-mobile-motivations-determining-factors-and-impacts-of-the-emigration-andreturn-migration-of-german-citizens/. Last accessed 30 April 2020.

${ }^{3}$ https://www.destatis.de/EN/FactsFigures/SocietyState/Population/. Last accessed 30 April 2020. Migration/Tables/MigrationGerman.html;jsessionid = D91ACD3B76E67029C59A109D2091 8B39.InternetLive. Last accessed 30 April 2020.

${ }^{4}$ OECD (2015), Connecting with Emigrants: A Global Profile of Diasporas 2015, https://www. oecd.org/publications/connecting-with-emigrants-9789264239845-en.htm. Last accessed 30 April 2020.

${ }^{5}$ https://esa.un.org/miggmgprofiles/indicators/files/Germany.pdf. Last accessed 30 April 2020.

${ }^{6}$ See footnote 2 SVR (2015).
} 
$70 \%$ of emigrants having tertiary education, compared to $64 \%$ of non-migrants. Over half $(57 \%)$ were highly skilled professionals, compared to $20 \%$ of the nonmobile citizens. This is a single study, and perhaps not generalizable, but does give valuable insights into this population.

\subsubsection{Diaspora Infrastructure}

The Emigrant Protection Act (Auswandererschutzgesetz), passed into law in 1975, amended the previous Imperial Act on Emigration (Reichsgesetz über das Auswanderungswesen) of 1897, which protected emigrants from unscrupulous agents claiming to facilitate emigration. The 1897 Act also included limits on emigration, notably for those who had not yet completed military service, for whom an arrest warrant had been issued, or whose travel expenses had been paid for or advanced by a foreign Government. ${ }^{7}$ The 1975 Emigrant Protection Act removed the limitations on emigration and, indeed, was based upon the premise of the right of citizens to emigrate freely, and sought to ensure that this right remained unrestricted, also ensuring that citizens are properly prepared for emigration, without being charged for that service. ${ }^{8}$

The Emigrant Protection Act, most recently amended in 2013, in which policies were made uniform across Germany, thus legislates and restricts who may advise German citizens on emigration. The Act firmly anchors the responsibility for the protection of emigrants with the federal Government, with the responsible authority the Federal Ministry for Family, Seniors, Women and Youth, which both coordinates advice through Caritas (Raphaelswerk e.V.) and Diakonisches Werk, as well as granting licenses to private providers. An evaluation of the Act was carried out in 2018 to establish whether it fulfills its goal of sufficiently informing today's potential migrants. ${ }^{9}$

The responsibility for collating and evaluating all information related to emigration, as well as about counseling offices, was delegated in 1958 to the Federal Agency for Emigrants and those Working Abroad (Bundesstelle für Auswanderer und Auslandstätige), unit ZMV II 6 in the BVA, Federal Office of Administration (Bundesverwaltungsamt), an agency of the Federal Ministry of Interior. ${ }^{10}$

This BVA unit does not process any claims of any sort, nor does it dispense advice. The unit's activities are limited to managing a web page which provides links to information concerning emigration from and return migration to Germany,

\footnotetext{
${ }^{7}$ https://ia902706.us.archive.org/23/items/dasreichsgesetz00goetgoog/dasreichsgesetz00goetgoog.pdf. Last accessed 29 May 2019.

${ }^{8} \mathrm{http} / / /$ dipbt.bundestag.de/doc/btp/07/07141.pdf. Last accessed 30 April 2020.

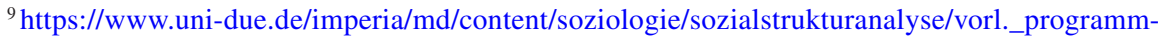
auswanderung _und_rüc kwanderung-adhoc-dgs2018.pdf. Last accessed 30 April 2020.

${ }^{10} \mathrm{http}: / /$ dipbt.bundestag.de/dip21/btd/13/035/1303530.pdf; brd/2012/04 57-12.pdf. Last accessed 29 May 2019.

http://dipbt.bundestag.de/doc/
} 
including links to information organized by country of residence. This information includes legal protection, foreign law, marriage abroad, useful information and FAQs, as well as links to the two primary advisory organizations (Raphaelswerk e.V. and Diakonisches Werk), other non-governmental associations which can give advice (e.g. "Deutsche im Ausland e.V"11), German ministries' information pages (about international drivers' licenses, education systems in specific countries, health care, welfare, unemployment benefits, etc.), chambers of commerce, etc. They do not provide information that is of their own production, and they explicitly note on their website that they do not give advice by telephone, in writing or in person. They are a clearinghouse of information, providing links to those who can give advice. They do note that they are able to provide immediate help to German nationals in emergency situations; they cite Chernobyl in 1986 and the Asian tsunami of 2004 as two cases where they did so. ${ }^{12}$

The BVA unit instead directs Germans considering emigration to the two welfare associations, Caritas/Raphaelswerk e.V. (associated with the Catholic Church) and Diakonisches Werk (associated with the Protestant Church). Located under the Federal Ministry for Family's authority, these associations are also financially supported by the Ministry and are responsible for advice on emigration and return to Germany. Support of German nationals abroad by the federal Government is, for the most part, on the basis of exception only, and would be handled by the Ministry in whose remit the question falls, after treatment of the case by a consular official.

Terminology The BVA unit refers to German emigrants and those working abroad, but the unit responsible for overseeing elections (appointed by the Ministry of Interior) refers to German nationals abroad as Auslandsdeutsche, or Germans abroad, a phrase that has been used in the past to refer to German ethno-national minorities (who are generally not German citizens). In a clear sign of change in the past twenty years, the term Auslandsdeutsche was once used by the Government to refer to German ethno-national minorities living in Eastern and Central Europe and the former Soviet Union. ${ }^{13}$ Government institutions now refer to these individuals as German minorities (Deutsche Minderheiten) rather than Germans living abroad, although some academics and think tanks do continue to use the term Auslandsdeutsche.$^{14}$ It is not an entirely uncontroversial term (Blackbourn 2015).

\footnotetext{
${ }^{11}$ https://www.deutsche-im-ausland.org. Last accessed 30 April 2020.

${ }^{12}$ https://www.bva.bund.de/DE/Themen/BuergerVerbaende/weitere/weitere_node.html. Last accessed 29 May 2019.

${ }^{13} \mathrm{http}: / / \mathrm{www} . b p b . d e / n a c h s c h l a g e n / l e x i k a / h a n d w o e r t e r b u c h-p o l i t i s c h e s-s y s t e m / 201982 /$ auslandsdeutsche? $\mathrm{p}=$ all. Last accessed 30 April 2020.

${ }^{14}$ http://www.bpb.de/ apuz/243866/deutsche-minderheiten-im-ausland?p=all. Last accessed 30 April 2020.
} 
The BVA - elsewhere - refers to Germans Abroad (Deutsche im Ausland), ${ }^{15}$ as does the Ministry of Interior at various points ${ }^{16}$ and the German Bundestag. ${ }^{17}$ No explanation is given in any of these cases.

German Minorities While there is thus no targeted assistance or support intended specifically for German nationals living abroad (any assistance is on the basis of exception, not the rule), the German Government does, on the other hand, provide centralized funding and support to German minorities living in Central and Eastern Europe and southern Denmark (but not elsewhere in the world). These are not, typically, German citizens. This is a distinct policy area handled by the Representative for Aussiedler and National Minorities (Beauftragter für Aussiedlerfragen und nationale Minderheiten) within the Ministry of Interior (Beauftragter 2018). The representative is responsible for these German minorities, including the minorities who migrate to Germany. This policy continues a post-war policy of reconciliation.

Government policy vis-à-vis German minorities, particularly those in the former Soviet Union, is thus separate from that addressing German nationals living abroad. While some of the minorities may have had their German citizenship recognized, the majority are not German citizens. The German Government's policy is in place to address the impact of the results of World War II on those minorities. This policy includes support for the German language, maintenance and development of ethnocultural identity, work with youth groups, partnerships, and strengthening selforganization of the minorities. ${ }^{18}$ Faced with increasing immigration of these minorities in the 1990s, the German Government phrase which represented the shift from supporting their migration to supporting them in their countries of residence was "Hilfe zur Selbsthilfe" or help for self-help. ${ }^{19}$ A high point of so-called Aussiedler (or out-settler) migration was reached in 1990, with nearly 400,000 migrants from CEE and the former Soviet Union to Germany, dropping to 1800 in $2012 .^{20}$

Registration All individuals living in Germany - both German and foreign nationals - are required, within one or 2 weeks (variation across federal states) of moving in to a residence, to register with the local authorities, a common procedure across

\footnotetext{
${ }^{15} \mathrm{https}: / /$ www.bva.bund.de/DE/DasBVA/Rueckblick/rueckblick-node.html. Last accessed 29 May 2019.

${ }^{16} \mathrm{https}: / / \mathrm{www}$. bmi.bund.de/DE/themen/moderne-verwaltung/verwaltungsrecht/personenstandsrecht/personenstandsrecht-node.html. Last accessed 30 April 2020.

${ }^{17}$ https://www.bundestag.de/blob/502398/9b86244c1c207ce4bbae402a5441f17e/wd-6-144-16pdf-data.pdf. Last accessed 30 April 2020.

${ }^{18} \mathrm{https} / /$ www.bmi.bund.de/DE/themen/heimat-integration/minderheiten/minderheiten-in-europa/ minderheiten-in-europa-node.html. Last accessed 29 May 2019.

${ }^{19} \mathrm{https} / / / \mathrm{www}$. bundestag.de/blob/414952/a175b9dd999482c63b85bdd12ade0592/wd-2-100-06pdf-data.pdf. Last accessed 30 April 2020.

${ }^{20} \mathrm{https}$ //Www.zeit.de/news/2018-01/14/migration-zahl-der-spaetaussiedler-steigtweiter-14094202. Last accessed 30 April 2020.
} 
Europe. Local registration in Germany is a prerequisite for access to services such as the monthly child allowance, social support, welfare, unemployment benefits, training programs, etc. On the other hand, individuals who are permanently leaving one residence, and whose next residence is not in Germany, must de-register within 2 weeks of leaving that German residence (BMG, Federal Registration Act, Bundesmeldegesetz). This de-registration is used to calculate the number of Germans who have emigrated, which does mean that those who are intending to leave Germany only temporarily are not captured in the data. De-registration entails losing the majority of the rights gained through registration.

It is clear that many Germans will have left Germany, but nonetheless remain registered. It is unknown how many people have not de-registered; the German Government notes that because of varying national abilities in host countries to check and sanction registration, there will always be some number who have not de-registered, ${ }^{21}$ despite a potential 1000 EUR fine. ${ }^{22}$

Responding to concerns about domestic address fraud, the Registration Act (Meldegesetz) was amended in 2015 to require a landlord's signature for both registration and de-registration. This means that a previous interim solution for remaining registered in Germany - giving a friend's address, for instance - becomes more complicated, as it now requires submitting paperwork claiming emigrant as tenant.

German citizens living abroad have the possibility of signing up, for the purposes of emergency notification, with the Electronic Recording of Germans Abroad (Elektronische Erfassung von Deutschen im Ausland, Elefand) managed by the Foreign Office. Elefand is designed for travellers and temporary migrants and does not require de-registration from a domestic German address. It also includes those Germans who are living abroad indefinitely or permanently, so that they can be contacted in case of national crisis. One question which is asked on the registration page is whether an individual is travelling for a brief period or is living abroad longer-term or indefinitely. In registering on Elefand, individuals are not asked whether they remain registered in Germany, ${ }^{23}$ but they do agree to a standard data use statement. It is unclear whether, but unlikely that, Elefand would crosscheck to verify whether an individual is registered in Germany.

Consular Network The consular network providing support to German nationals abroad is well developed, with a worldwide total of over 220 representations (embassies and consulates), and over 330 honorary consuls. In the countries hosting the five largest populations of German nationals living abroad (United States, United Kingdom, Switzerland, France and Italy), there are a total of 19 embassies and consulates and 84 honorary consulates ( 9 and 36 in the United States; 2 and 17 in the UK; 1 and 4 in Switzerland; 5 and 18 in France, and 2 and 9 in Italy). The

\footnotetext{
${ }^{21} \mathrm{http} / / /$ dip21.bundestag.de/dip21/btd/16/054/1605417.pdf. Last accessed 30 April 2020.

${ }^{22} \mathrm{https}$ ://wirelesslife.de/wohnsitz-aus-deutschland-abmelden-pros-und-cons/. Last accessed 30 April 2020.

${ }^{23}$ https://elefand.diplo.de/elefandextern/home/login!form.action. Last accessed 30 April 2020.
} 
Consular Act (Gesetz über die Konsularbeamten, ihre Aufgaben und BefugnisseKonsulargesetz) of 11 September 1974 is the Act that governs the appointment and duties of consular and honorary consular officials. Honorary consular officials are charged with consular duties, including the issuing of passports and emergency assistance to citizens. The Federal Foreign Office (Auswärtiges Amt), through embassies and consulates, is the responsible Ministry. ${ }^{24}$

In the absence of German diplomatic representation, German citizens may also draw on any of the consular services of any other European Union (EU) country, following the Consular Protection Directive of 20 April 2015..$^{25}$

Political Parties The four major political parties (Christian Democrats (CDU), Social Democrats (SPD), Free Democrats (FDP) and Alliance 90/Greens) have a limited number of branches located abroad, established by individual German citizens living abroad. The CDU has the "Circles of friends abroad" (Freundeskreise im Ausland $)^{26}$ in 21 countries, with the first one established in Brussels in 1996. The Social Democrats refer to "Friendship circles abroad" (Auslandsfreundeskreise), with their largest group, founded in the 1970s and counting with over 240 members, being in Brussels. ${ }^{27}$ There are 14 further SPD circles, with another eight currently being established by German nationals living abroad. The FDP's first "Group abroad" (Auslandsgruppe) was established in Brussels in 1969. There are six further FDP groups, all located in Europe..$^{28}$ The Greens have two "Local associations" (Ortsverbände) outside of Germany: one in Brussels ${ }^{29}$ and another one established in 2008 at the Goethe Institut in Washington, DC. ${ }^{30}$

Taxation In principle, Germans living abroad are not taxed on their income earned abroad. Double taxation agreements have been concluded between Germany and 94 countries, including the five hosting the largest populations of German citizens, to avoid double taxation on any other income. The German Finance Ministry provides links to the text of the agreements, as well as information concerning taxation of foreign businesses or foreign income (albeit directed at German residents). ${ }^{31}$

\footnotetext{
${ }^{24}$ https://www.auswaertiges-amt.de/blob/199314/c63baf4e51669ec9cf35d06fe3f9350b/dtauslandsvertretungenliste-data.pdf. Last accessed 29 May 2019.

${ }^{25} \mathrm{https}$ ://eur-lex.europa.eu/legal-content/EN/TXT/?uri=CELEX\%3A32015L0637. Last accessed 30 April 2020.

${ }^{26} \mathrm{https}: / / \mathrm{www} . c d u . d e / a u s l a n d s d e u t s c h e$. Last accessed 30 April 2020.

${ }^{27} \mathrm{https} / / / \mathrm{www}$. spd.de/partei/organisation/auslandsfreundes kreise/. Last accessed 29 May 2019.

${ }^{28} \mathrm{https}: / / \mathrm{www} . \mathrm{fdp}-$ europa.eu. Last accessed 30 April 2020.

${ }^{29} \mathrm{https}$ ://gruene-bruessel.eu/ueber-uns/. Last accessed 30 April 2020.

${ }^{30} \mathrm{https} / / /$ gruene-washington.de/ neuigkeiten/. Last accessed 30 April 2020.

${ }^{31} \mathrm{https}: / / \mathrm{www}$. bundesfinanzministerium.de/Content/DE/Standardartikel/Themen/Steuern/ Internationales_Steuerrecht/Staatenbezogene_Informationen/doppelbesteuerungsabkommen. html. Last accessed 29 May 2019.
} 


\subsubsection{Key Engagement Policies}

There does not appear to be any concerted coordination between German ministries addressing German nationals living abroad. The Emigration Protection Act ensures that correct information is given to those who are considering a move abroad, which may well account for the inclusion of references to Germans living abroad in a number of Acts. There are distinct differences in policies and procedures for German citizens living abroad in the EU and in European Economic Area (EEA) countries than elsewhere. These are slight differences for voting, and more significant ones for consular protection and access to social protections.

Voting Voting from abroad is one policy area with significant positive developments in recent years, in line with other countries' expansion of the right to vote from abroad (Bauböck 2005). The right to vote was granted to German citizens living abroad (aged 18 and older) in 1985, with that right both expanded and facilitated since then (Pautsch and Müller-Török 2016).

Germans living abroad have the right to both the passive suffrage (the right to stand as candidate in elections) and active suffrage (the right to vote). Any German living abroad - whether temporarily (still registered at a domestic German address) or permanently (de-registered from a previous residence in Germany) - who is 18 or older may vote in the Bundestag (federal Parliament) elections. However, only those who are temporarily abroad may additionally vote in state and local elections; those who are permanently abroad may vote only in federal and European Parliament elections. However, any German living abroad, whether temporarily or permanently, may run for any level of office - European Parliament, federal, state or local.

To be eligible to vote in federal elections, Germans living abroad must not be excluded from voting by a judge (for instance, for having committed a severe crime), be at least 18 years old and either have lived in Germany for at least three uninterrupted months after the age of 14 within the last 25 years (last legislative change in 2009) or demonstrate that they are personally familiar with the political situation in Germany and are affected by it (legislative change in 2013, following a court case brought by two German citizens living in Belgium, who were excluded from voting). ${ }^{32}$ Passively following the news is not enough; examples are presented by the federal election coordinator and might include an employee of the Goethe Institut, a journalist working for a German publication or broadcaster, or a young person who has never lived in Germany, but visits regularly, even if each visit is less than

\footnotetext{
${ }^{32} \mathrm{https}: / / w w w . d w . c o m / d e / n e u e s-w a h l r e c h t-f u ̈ r-a u s l a n d s d e u t s c h e / a-16797154$. Last accessed 30 April 2020.
} 
three months ${ }^{33}$ Prior to the 2013 amendment, those who had never lived in Germany were excluded from voting ${ }^{34}$ (Pautsch and Müller-Török 2016).

To vote, citizens must request inclusion on a local voter registration roll. The request form can be downloaded from the website of the Federal Returning Officer (Bundeswahlleiter - the federal voting bureau) or picked up from embassies or consulates..$^{35}$ It is available 9 months before the election. It must be received at least 21 days before the election by the last place of residence in Germany or, for those who have never resided in Germany, to the locality where the closest connection has been demonstrated or the last place of residence of parents. Upon receipt of the request, the ballot will be sent to the foreign address given. The ballot must be received by the local voting office by 6 p.m. on election day. If the foreign postal service is unreliable, request and ballot may be sent and received via consulate or embassy. The federal returning officer holds a list of those locations deemed to have unreliable post, and where such service is available. In principle, however, voting nonetheless remains postal only. ${ }^{36}$

European Parliament elections have slightly different procedures. To vote in these elections, non-resident German citizens must have lived in Germany or a Council of Europe country for at least 3 months within the last 25 years. ${ }^{37}$ They request inclusion on a local voter registration roll; the request form is available 9 months before the election on the website of the Bundeswahlleiter and at diplomatic missions abroad. Upon receipt of the request, the ballot will be sent to the foreign address given and it must be returned to the local voting office by 6 p.m. on voting day. If the foreign postal service is unreliable, both request and ballot may be sent and received via consulate or embassy; voting remains postal only. German citizens living in another EU country may vote for European Parliament elections either in Germany or in their country of residence.

Consular Support The Consular Act, as noted above, governs the actions that consular officers can take vis-à-vis German nationals abroad. There is a great deal of discretion granted to consular officials. Although the law defines whether the consular authority may intervene, if intervention is legally permitted, the consular officer's discretion is substantial, in form, type and degree (Lenz 2017, 183).

\footnotetext{
${ }^{33}$ https://www.bundeswahlleiter.de/dam/jcr/49fd7b4e-436c-45c3-baed-e9d8ffb8c547/anwendungshinweise_12_bwg.pdf. Last accessed 30 April 2020.

${ }^{34} \mathrm{https}: / /$ www.bundestag.de/bundestagswahl2017/auslandsdeutsche/213246. Last accessed 30 April 2020.

${ }^{35} \mathrm{https}$ ///www.bundeswahlleiter.de/info/presse/mitteilungen/bundestagswahl-2017/06_17_ deutsche_im_ausland_antrag.html. Last accessed 29 May 2019.

${ }^{36} \mathrm{https}: / / \mathrm{www}$. bundeswahlleiter.de/bundestagswahlen/2017/informationen-waehler/deutsche-imausland.html\#1caa4dd1-5f18-4cbe-8af5-eeed483a69b7. Last accessed 30 April 2020.

${ }^{37}$ https://www.dw.com/de/wählen-aus-dem-ausland-so-geht-es/a-1645952. Last accessed 30 April 2020.
} 
The Ministry of Foreign Affairs has a page clearly stating what consular and honorary consular officers may and may not do for Germans living abroad. ${ }^{38} \mathrm{~A}$ consular officer may, in an emergency situation, offer advice, issue a replacement passport, help an individual to contact a friend or relative, inform him/her about means of receiving money, arrange for a lawyer in the case of arrest, issue a certificate of death or birth and, in the case of the death of a German citizen, notify next of kin and give information about dealing with formalities, including arranging for the transportation of the remains of a deceased German to Germany. More routine procedures include registrations of births of German citizens abroad, issuance and renewal of passports, issuance and/or signature of various certificates, etc.

The European Consular Protection Directive of 20 April 2015 was transposed into German law on 1 May 2018. $\S 9$ a of the Consular Act is the specific legal transposition, allowing German citizens to receive help from other EU consular officials, if Germany does not have representation in a given country. ${ }^{39}$

All German citizens living abroad may request a passport. An appointment must be made, and the individual must come to the consulate in person. Previous passport, birth certificate (in original and one copy), certificate of de-registration from Germany (unless previous passport already reflects residence abroad), two passport photos and a form are required. For minors, additional forms, such as parents' marriage certificate, or proof of parents' German citizenship, may be required.

Children born abroad to a German citizen receive German citizenship at birth, as long as that birth is registered at a consulate within one year. A child may hold two or more citizenships from birth, if, for instance, born to a German and a non-German parent and/or if born in a country with jus soli attribution of citizenship. From the German perspective, there is no need to choose one of the citizenships at any point. Adult Germans who choose to acquire another citizenship (aside from EU states and Switzerland), must, in principle, give up their German citizenship. However, exceptions can be applied for, and are granted on various bases, in accordance with the Citizenship Law (Staatsangehörigkeitsgesetz).

Even though there is considerable discretion for consular officers under various articles of the Consular Act (see below), there are clear points in which they may not engage. For instance, they may not issue drivers' licenses, pay hotel, hospital or other bills or fines, intervene in court proceedings, act as a lawyer or a branch of a travel office, bank or health insurance, pay extremely high costs of a search and rescue action, or pay for the costs of transporting a deceased person's remains to Germany.

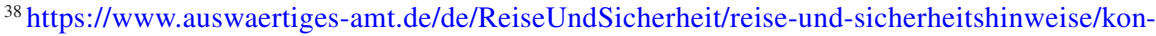
sularinfo/hilfe-av. Last accessed 29 May 2019.

${ }^{39} \mathrm{https} / / /$ www.bundesrat.de/DE/plenum/bundesrat-kompakt/18/966/966-node.html\#top-1. Last accessed 29 May 2019.
} 


\subsubsection{Cultural Institutions}

German Schools The coordination of the German Schools Abroad (Deutsche Auslandsschulen) was taken over by the BVA in 1968, coordinating material, pedagogical and financial support of those schools. Financed in part by the German Foreign Office, there are 140 German schools abroad, aiming to provide foreign (local) and German students with a German Abitur (high school leaving certificate) and access to higher education and technical training in Germany. Of the 82,000 students enrolled in German schools worldwide, about one-third are German citizens. Substantial fees are charged. Although German schools may serve as - and often do - focal points for a local German population, there is no preferential treatment for German nationals abroad, whether with regard to admissions policies, recruitment or fees.

Deutsche Welle Established in 1953, Deutsche Welle (DW) radio and television is a German public broadcaster financed by federal tax funds. Its stated aim has changed over the years. DW was initially intended to counter Soviet propaganda about West Germany, as well as providing information to East Germans, with the aim of maintaining German unification as a goal. ${ }^{40}$ Today's goals, as laid out in the 2004 Deutsche Welle Act, ${ }^{41}$ are to foster the German language, to disseminate information about Germany as a democratic state, and to lead to cultural exchange. While it certainly will attract Germans, this is not its stated aim.

Goethe Institute The Goethe Institut ${ }^{42}$ is Germany's cultural institute aiming to provide German instruction for those who wish to learn German and create focal points for education and culture. Its primary audience is non-Germans (for instance, students or applicants for spousal visas in Germany must demonstrate German language competences and can seek training and/or testing at the Goethe Institute). The first Goethe Institute was established in 1952 in Athens. Currently, there are 159 Goethe Institutes in 98 countries and more than 1100 points of contact including cooperative arrangements for language testing, reading rooms, German-foreign cultural associations, etc. Primarily intended as a place of cultural encounter and education, the Goethe Institute's programs cover a range of topics, some more appropriate for language learners, others appealing to a German audience as well. Goethe Institute premises certainly do serve as host for events for Germans from time to time, but this is not its intended focus or function.

Return There are several possibilities for highly-skilled Germans to receive financial support to return to Germany. The Return Stipendia for Germans Abroad

\footnotetext{
${ }^{40}$ https://www.bundestag.de/resource/blob/406622/efa899d31b03a229a4c201e59d36e003/ WD-10-098-15-pdf-data.pdf. Last accessed 30 April 2020.

${ }^{41}$ https://www.dw.com/downloads/26315376/dwgesetzneues-cd.pdf. Last accessed 30 April 2020.

${ }^{42} \mathrm{https}: / /$ www.goethe.de/en/index.html. Last accessed 30 April 2020.
} 
(Rückkehrstipendien für Deutsche aus dem Ausland) are financed by the German Academic Exchange Service (Deutscher Akademischer Austauschdienst - DAAD). There are a number of stipendia available for German scientists seeking to return to Germany ${ }^{43}$ These initiatives are financed by various German ministries, particularly the German Foreign Office, as well as with EU funding and others, including government and private. This initiative is intended to support German academic institutions' recruitment goals, not primarily as a means of assisting academics. Some German federal states are undertaking their own return initiatives - Bavaria invites Germans living abroad to "Return to Bavaria", while Brandenburg encourages former Brandenburg residents to return, either from elsewhere in Germany or from abroad. All training would occur after a successful application for such a program, and after a return to Germany, and not in preparation for a return.

\subsection{Diaspora Policies and Social Protection in Germany}

As noted above, with the exception of pensions, social protection is available to Germans living abroad only on the basis of exception. The Consular Act is the most relevant legislation, with $§ 5$ - "Assistance for Individuals" - allowing for discretionary actions by consular officials under emergency and unusual circumstances.

Above all, the philosophy underlying social protection policies is that of rights being granted on the basis of the place of residence. These rights are available to those who live in Germany. For German nationals living abroad, exceptions extending protection can be contemplated only if the rights are not available, or not available to that individual, in the country of residence. $\$ 5$ (1) specifies that help shall not be given to dual citizens whose habitual place of residence is the country of their second citizenship.

This philosophy of the residence-based rights also underlies and explains the substantial provision of pensions to German nationals abroad - pension rights accrue on the basis of past contributions and the pension is not granted on the basis of current residence or status. Insofar, the logic of rights based on residence is upheld with this seemingly exceptional protection.

Consular officials are granted broad discretion. They are instructed to respect and support relations between Germany and the country of their posting, in particular to support the foreign relations and development relations, as well as traffic rules, culture and law. They are further instructed to give German citizens assistance and advice, as appropriate. They are not instructed explicitly to work with any Ministry in Germany, except in their role as civil servants of the Foreign Office.

In terms of information strategies, the Federal Foreign Office and the Federal Agency for Emigrants and those Working Abroad have extensive and substantial

\footnotetext{
${ }^{43} \mathrm{https} / / /$ www.daad.de/ausland/reintegration/stipendien/de/22184-rueckkehrstipendien-fuerdeutsche-aus-dem-ausland/. Last accessed 29 May 2019.
} 
information on the provision - as well as on the lack of provision - of rights and protection abroad. Both provide links to relevant Ministries, where further information on (the limited) access to rights is given.

With respect to repatriation, $\S 5$ of the Consular Act states that in strictly defined single cases, "if it is advisable", generally in an emergency situation, a consular officer's help may include enabling an individual's return to his/her place of habitual residence, or to another place. Any such costs are to be repaid by the individual. Furthermore, $\S 6$ of the Consular Act specifies that under generalized situations of catastrophe, including natural disaster, war or revolutionary developments, consular officials shall take necessary measures to offer help and protection. Any costs that arise are to be repaid, although exceptions can be made if the situation in the country or an individual's personal circumstances are such that repayment is not possible. The Foreign Office website includes a story about the evacuation of 200 German and EU citizens in 2016 from South Sudan, as heavy battles broke out. They were evacuated to Uganda, and from there, travel back to Germany or elsewhere was arranged. ${ }^{44}$

\subsubsection{Unemployment}

With respect to drawing unemployment benefits while abroad, there are substantial differences for a German citizen residing in an EU Member State or in a non-EU country. There are also differences between EU countries and third countries as to whether an individual moves out of Germany while unemployed, or loses a job while living abroad.

A German citizen drawing unemployment support may, on application, and after 4 weeks, move to another EU country or Switzerland in search of work. The move is in principle limited to 3 months, but can be extended to a maximum of 6 months. ${ }^{45}$ The legal basis for unemployment support is laid out in the Third Social Code (Sozialgesetzbuch III), Labor Promotion (Arbeitsförderung) §137.

Unemployment support (Arbeitslosengeld) is not paid to Germans who have returned to Germany from working abroad, who lost that employment and remain unemployed. They should draw on the unemployment system of their country of employment (although they may have lost that right by returning to Germany). In the case of a move from an EU country, an application can be made prior to migration to continue drawing on that support in Germany for a maximum of 3 months.

On the other hand, employment in another EU country or Switzerland can be calculated in to the required 12 months of employment (within the previous 2 years) necessary for unemployment benefits, as long as there has been subsequent

\footnotetext{
${ }^{44} \mathrm{https} / / / \mathrm{www}$. auswaertiges-amt.de/de/aussenpolitik/laender/suedsudan-node/160714-evakuierung/282266. Last accessed 29 May 2019.

${ }^{45}$ https://con.arbeitsagentur.de/prod/apok/ct/dam/download/documents/dok_ba013155.pdf. Last accessed 29 May 2019.
} 
employment in Germany. ${ }^{46}$ The unemployment must arise after the employment in Germany, regardless of how short that period of employment in Germany is. Unemployment assistance will not be granted on the basis of employment abroad only. This does not apply for a third country: a German citizen can not draw on time worked in a non-EU country in calculating eligibility for unemployment support, even if it is followed by employment in Germany. Only the time in Germany or an EU country or Switzerland will count.

Training abroad is supported by the German Government only insofar as it is part of a training program based in Germany, and the training outside of Germany is an integral part of that training ( $\$ 58)$. Programs supporting returning Germans is limited to those addressed above, within the context of a return of highly-skilled German nationals.

In the case of German citizens who have returned from abroad and do not qualify for unemployment support (Arbeitslosengeld), they would then be eligible for unemployment support, part II (Arbeitslosengeld II), colloquially known as Hartz $I V$ (see below). For those individuals who are above retirement age or who are disabled, a different support mechanism applies, as described below.

\subsubsection{Health Care}

Health insurance, in principle, covers only care in Germany. German citizens who hold health insurance in Germany are, however, covered in EU and EEA states, on presentation of the EHIC (European Health Insurance Card), and only for brief trips. Individuals who are normally employed in Germany and are sent on a work assignment to another EU/EEA state for a short period may continue to hold health insurance in Germany. Germany holds agreements with several states (Israel, Tunisia and Turkey $^{47}$ ) by which German health insurance - if the individual is insured and normally resident in Germany - will cover health care costs in those countries. Otherwise, individuals are advised to take out an additional travel health insurance or, in the case of emigration, are expected to be insured in their country of destination.

\subsubsection{Pensions}

Individual access to pensions is the other policy area (in addition to voting) with a clear inclusion of German nationals living abroad. Indeed, German citizens who had earned an income in Germany and now live abroad have the same eligibility for

\footnotetext{
${ }^{46} \mathrm{https}$ //con.arbeitsagentur.de/ prod/apok/ct/dam/download/documents/dok_ba013155.pdf. Last accessed 29 May 2019.

${ }^{47}$ https://www.bundesgesundheitsministerium.de/fileadmin/Dateien/5_Publikationen/Gesundheit/ Broschueren/BMG_Krankenversicherung_Ratgeber.pdf. Last accessed 29 May 2019.
} 
pensions as those currently residing in Germany. To be eligible, an individual who has reached pensionable age must have worked in Germany for at least 5 years. An individual who has reached the age of early retirement (63 years of age) must have worked for 35 years. While there are some exceptions in which pensions can be limited (although not in other EU/EEA countries), for the most part, pensions earned in Germany are accessible to all of those who have since moved abroad. Germans living abroad receive pensions based upon the time worked in Germany. For questions of taxation - pensions are taxable, although depending on the level, tax may or may not be due - for those who live outside of Germany, and whose only income from Germany is a pension, the Finance Office in New Brandenburg is responsible. ${ }^{48}$ Annual income statements must be provided to the Finance Office; these can be signed by consular and honorary consular authorities, with the form available on the embassy webpage.

Pensions can be applied for from either within Germany or abroad. The German pension scheme website explains eligibility and gives information on pensions and social insurance. ${ }^{49}$ Information is available on how to apply, and on the procedures in place. Pensions are paid directly by the pension insurance scheme (Rentenversicherung) into the individual's bank account. In order for this to happen, a life certificate (Lebensbescheinigung) and a citizenship certificate (Staatsangehörigkeitsbescheinigung) are required for the payments to be initiated. Both consular and honorary consul authorities can issue these certificates. The "Pensions without borders" (Rente ohne Grenzen) page gives information on drawing pensions abroad, as well as on the procedures for combining work abroad and work in Germany for a pension in Germany or abroad.

For those who have not worked the minimum time in Germany, there are agreements both within EU and with EEA countries as well as with numerous other countries ${ }^{50}$ which allow for cumulating the contribution period; time worked in one or more of these countries counts as if the time had been worked in Germany.

For those German citizens, normally resident in Germany, who have not been formally employed for the minimum time period for eligibility and who are above retirement age, a basic security (Grundsicherung) is guaranteed. This does not apply to those living outside of Germany.

\footnotetext{
${ }^{48} \mathrm{https}: / / \mathrm{www}$. finanzamt-rente-im-ausland.de/de/. Last accessed 30 April 2020.

${ }^{49} \mathrm{https} / / /$ www.deutsche-rentenversicherung.de/Allgemein/de/Navigation/2_Rente_Reha/01_ Rente/01_allgemei nes/05_rente_und_ausland/grundlagen_node.html. Last accessed 29 May 2019. ${ }^{50} \mathrm{https}$ ///www.bundestag.de/resource/blob/502398/9b86244c1c207ce4bbae402a5441f17e/ WD-6-144-16-pdf-data.pdf; https://www.bmas.de/DE/Themen/Soziales-Europa-undInternationales/Meldungen/sozialversicherungsabkommen.html. Last accessed 29 May 2019.
} 


\subsubsection{Family-Related Benefits}

The Federal Child Benefit Act (Bundeskindergeldgesetz) allows for the payment of a monthly cash benefit per child until the age of 18 (or 25 if the child is in full-time education); this applies to all children registered in Germany, regardless of citizenship and regardless of income level. For German children living abroad, parents may receive the cash benefit if at least one parent is a general tax payer in Germany (e.g. has been sent abroad by a German employer for a defined time period or is a civil servant working abroad), or if at least one parent is paid as a development worker or missionary. ${ }^{51}$ In the case of divorced or separated parents, the child benefit is, in domestic German cases, paid to the parent with whom the child lives. If one parent lives outside of Germany, and has primary custody of the child/children, then the parent living in Germany does not receive the child benefit. The parent living outside of Germany receives a child benefit only in line with the relevant national legislation, not German legislation.

\subsubsection{Economic Hardship}

German citizens living abroad are not eligible for any form of welfare payment or social assistance. German citizens who return to Germany, are unemployed and who do not qualify for unemployment support are, however, eligible for unemployment support II (Arbeitslosengeld II), or Hartz IV, but only upon a return to Germany. The eligibility requirements for Hartz $I V$ are that individuals are aged over 15, are able to work a minimum of $3 \mathrm{~h}$ per day, have their usual residence in Germany, and do not have sufficient (household) income to survive. Arbeitslosengeld II, unlike Arbeitslosengeld, cannot be taken to another EU/EEA country.

Financial assistance to Germans living abroad is possible only under exceptional circumstances. \$5 Consular Act, Assistance for individuals (Hilfeleistung an einzelne), specifies that in strictly defined single cases, if it is advisable, a consular officer may offer financial assistance. Any such costs are to be repaid. Open hotel or hospital costs or fines will not be paid.

If an emergency situation continues for more than 2 months, and it is not possible for the individual to return to Germany (due to child care responsibilities, lengthy hospitalization or imprisonment), then Book 12 of the Social Code shall be applied $(\S 24) .{ }^{52}$ Assistance will not be given if it would normally be expected from the

\footnotetext{
${ }^{51} \mathrm{https}$ ://con.arbeitsagentur.de/prod/apok/ct/dam/download/documents/KG2MerkblattKindergeld_ba015394.pdf. Last accessed 29 May 2019.

${ }^{52}$ Sozialgesetzbuch (SGB) Zwölftes Buch (XII) - Sozialhilfe. https://dejure.org/gesetze/SGB_ XII/24.html. Last accessed 29 May 2019.
} 
country of residence ${ }^{53}$ Such assistance would be processed by the local social authorities, together with consular officials. This policy came into force in 2004 and is a restriction of the earlier policy, which was based on discretionary procedures, but had more flexibility. Consular officials can put individuals into contact with NGOs that provide assistance.

A court case sheds some light on how this might work in practice: a German man sought welfare, arguing in 2010 that he had lived in Thailand since the 1990s, "with short interruptions", had a child who only spoke Thai, and that he needed to remain in Thailand to care for her. The court found that, since he had been registered in Germany for lengthy periods in the 2000s, he could not be said to have lived nearly continuously in Thailand, and the request for social assistance was denied (Fredi Skwar 2016). Social assistance or welfare support for Germans living abroad remains the exception.

\subsection{Conclusions}

Although Germany now solidly recognizes itself as an immigration country, the memory of being an emigration country still affects its policies, with protection of emigrants from unscrupulous agents being one key element. Germany still seems to maintain an overriding belief that those who have emigrated have, in doing so, severed all ties and connections. Germany seems not to think of Germans abroad living long-term or permanently abroad as a population of citizens maintaining ties, or needing assistance, but rather as having become citizens or long-term residents elsewhere, perhaps because of its long history as an emigration country. Indeed, there is neither an explicit emphasis on German emigrants nor are there many policies in place which are intended specifically for them. Rights are largely granted on the basis of residence (in Germany), rather than (German) citizenship. Two exceptions do emerge, with access to voting rights and to pension rights strongly facilitated. Other rights are granted only on an exceptional basis, with consular authorities playing a role in facilitating that access.

Acknowledgements This chapter is part of the project "Migration and Transnational Social Protection in (Post)Crisis Europe (MiTSoPro)" that has received funding from the European Research Council (ERC) under the European Union's Horizon 2020 research and innovation programme (Grant agreement No. 680014). In addition to this chapter, readers can find a series of indicators comparing national social protection and diaspora policies across 40 countries on the following website: http://labos.ulg.ac.be/socialprotection/.

\footnotetext{
${ }^{53}$ https://www.bundestag.de/resource/blob/502398/9b86244c1c207ce4bbae402a5441f17e/ WD-6-144-16-pdf-data.pdf. Last accessed 30 April 2020.
} 


\section{References}

Bade, K. J. (1995). From emigration to immigration: The German experience in the nineteenth and twentieth centuries. Central European History, 28(4), 507-535.

Bauböck, R. (2005). Expansive citizenship: Voting beyond territory and membership. PS: Political Science and Politics, 38(4), 683-687.

Beauftragter der Bundesregierung für Aussiedlerfragen und nationale Minderheiten. (2018). Deutsche Minderheiten im Ausland. https://www.aussiedlerbeauftragter.de/AUSB/DE/ Themen/deutsche-minderheiten/deutsche-minderheiten_node.html

Blackbourn, D. (2015). Germans Abroad and Auslandsdeutsche. Geschichte und Gesellschaft, 41(2), 321-346. https://doi.org/10.13109/gege.2015.41.2.321.

Brodmerkel, A. (2017). Einwanderungsland Deutschland. Bundeszentrale für politische Bildung. http://www.bpb.de/politik/innenpolitik/demografischer-wandel/196652/ einwanderungsland-deutschland

Cordell, K., \& Wolff, S. (2007). Germany as a kin-state: The development and implementation of a norm-consistent external minority policy towards Central and Eastern Europe. Nationalities Papers, 35(2), 289-315.

Fredi Skwar. (2016). Zur Sozialhilfe für Deutsche im Ausland (hier: Lebensmittelpunkt Thailand). https://rabüro.de/zur-sozialhilfe-fuer-deutsche-im-ausland-hier-lebensmittelpunkt-thailand/

Klekowski von Koppenfels, A. (2002). The devolution of privilege: The legal background of the migration of ethnic Germans. In D. Rock \& S. Wolff (Eds.), Coming home to Germany? The Integration of Ethnic Germans from Central and Eastern Europe in the Federal Republic. Oxford: Berghahn Books.

Klekowski von Koppenfels, A. (2009). From Germans to migrants: Aussiedler migration to Germany. In T. Takeyuki (Ed.), Diasporic homecomings: Ethnic return migration in comparative perspective (pp. 103-132). Palo Alto: Stanford University Press.

Klekowski von Koppenfels, A. \& Costanzo, J. (2013). Counting the uncountable: Overseas Americans. Migration Information Source. http://www.migrationinformation.org/USfocus/ display. $\mathrm{cfm}$ ?ID=951

Klekowski von Koppenfels, A., \& Höhne, J. (2017). Gastarbeiter migration revisited: Consolidating Germany's position as an immigration country. In J.-M. Lafleur \& M. Stanek (Eds.), Southnorth migration in times of crisis. New York: Springer Open, IMISCOE Research Series.

Lenz, S. (2017). Der konsularische Schutz: Notfälle Deutscher im Ausland. PhD dissertation, University of Potsdam. https://publishup.uni-potsdam.de/opus4-ubp/frontdoor/deliver/index/ doc Id/40606/file/lenz_diss.pdf

Martin, P. L. (1994). Germany: Reluctant land of immigration. In Controlling immigration: A global perspective (pp. 189-225). Palo Alto: Stanford University Press.

Pautsch, A., \& Müller-Török, R. (2016). Das Wahlrecht der Auslandsdeutschen nach § 12 Abs. 2 BWG auf dem neuerlichen Prüfstand? Eine Analyse aus juristischer und verwaltungswissenschaftlicher Sicht. Zeitschrift für Parlamentsfragen, 47(4): 851-866 Seite 851-866, https://doi. org/10.5771/0340-1758-2016-4-851.

Schmidtke, O. (2017). Reinventing the nation: Germany's post-unification drive towards becoming a 'country of immigration'. German Politics, 26(4), 498-515.

Thränhardt, D. (1995). Germany: An undeclared immigration country. Journal of Ethnic and Migration Studies, 21(1), 19-35. 
Open Access This chapter is licensed under the terms of the Creative Commons Attribution 4.0 International License (http://creativecommons.org/licenses/by/4.0/), which permits use, sharing, adaptation, distribution and reproduction in any medium or format, as long as you give appropriate credit to the original author(s) and the source, provide a link to the Creative Commons license and indicate if changes were made.

The images or other third party material in this chapter are included in the chapter's Creative Commons license, unless indicated otherwise in a credit line to the material. If material is not included in the chapter's Creative Commons license and your intended use is not permitted by statutory regulation or exceeds the permitted use, you will need to obtain permission directly from the copyright holder. 